\title{
Comparison of EPS Extraction Efficiences from Cladophora Glomerata by Two Chemical Extraction Methods
}

\author{
Hwey-Lin Sheu, Shui-Ping Chang, and Yi-Chao Lee
}

\begin{abstract}
For a macroalga Cladophora glomerata, the extracellular matrix on the surface of algae cell, extracellular polymeric substances (EPS) has a gel-like structure that could fractioned into loosely bound EPS (LB-EPS) and tightly bound EPS (TB-EPS). The ratio of protein to polysaccharides $(\mathrm{P} / \mathrm{S})$ is TB-EPS is higher than LB-EPS. The contents and extraction rate of EPS were compared two chemical extraction methods (formaldehyde- $\mathrm{NaOH}$ and $\mathrm{NH}_{4} \mathrm{OH}$ ). The analysis demonstrated that more extraction rates of EPS were achieved by the formaldehyde- $\mathrm{NaOH}$ method. The protein to polysaccharides $\operatorname{ratio}(\mathrm{P} / \mathrm{S})$ in EPS is between 0.299 to 0.375 by formaldehyde- $\mathrm{NaOH}$ and between 0.232 to 0.374 by $\mathrm{NH}_{4} \mathrm{OH}$. The results indicated that the EPS could be efficiently extracted by the formaldehyde- $\mathrm{NaOH}$ method, but the influence of $\mathrm{P} / \mathrm{S}$ ratios were not obvious.
\end{abstract}

Index Terms-Cladophora glomerata, algae, extracellular polymeric substances (EPS), protein, polysaccharide

\section{INTRODUCTION}

EPS are the products of cellular lysis and hydrolysis of macromolecules with a high molecular weight, and they usually produced by microoganisms [1]-[3]. Based on binding force with cell, the EPS are usually divided into loosely bound EPS(LB-EPS) and tightly bound EPS(TB-EPS) [4]-[6].

Cladophora is a genus of large filamentous green algae commonly found in a variety of marine and freshwater and provides habitat and food for numerous organisms. It may be the most abundant macroalgae in freshwater worldwide [7]. The cell surface of $C$. glomerata can excrete large amounts of EPS and then form a unique mucilage layer. It is a high protential for EPS exploration algae. However, the EPS extraction methods of C. glomerata and the features of EPS were not explored.

The application of algae EPS in the industry has been valued. The demands for natural polymers in various industrial applications have increased, and therefore, novel algae have been used to synthesize high-value products [1], [8], [9].

This study compared the EPS extraction yield of the large freshwater algae C. glomerata and the levels of its primary major contents of polysaccharides and proteins with two different chemical extraction methods of $\mathrm{NH}_{4} \mathrm{OH}$ and

Manuscript received April 9, 2019; revised June 13, 2019.

The authors are with the Department of Environmental Engineering, Kun Shan University, No.195, Kunda Rd., YongKang Dist., Tainan City 710-03, Taiwan (e-mail: sheu@mail.ksu.edu.tw, spchang@mail.ksu.edu.tw, lyc007@mail.ksu.edu.tw). formaldehyde- $\mathrm{NaOH}$. We expect to establish an EPS extraction and analysis procedures biotechnology from $C$. Glomerata, and explore its potential in industrial development.

\section{MATERIALS AND METHODS}

\section{A. Algae and Microscopy}

In this study, the species C.glomerata were collected from the Zengwun River $\left(23^{\circ} 04^{\prime} \mathrm{N}, 120^{\circ} 04^{\prime} \mathrm{E}\right)$ in southern Taiwan. The algae with India ink was applied to visualize the EPS structure in mucilage layer of algae [10], [11] using the microscopy. The algae were washed twice with tap water, placed at room temperature for $2 \mathrm{~h}$ naturally drain, and then used for EPS extraction.

\section{B. EPS Extraction}

Samples were suspended in a $0.05 \% \mathrm{NaCl}$ solution and centrifuged at $5000 \mathrm{~g}$ for $20 \mathrm{~min}$, with the liquid collected for LB-EPS measurement [12], [13].

The remaining algae samples were resuspended with $0.05 \% \mathrm{NaCl}$ solution for TB-EPS extraction using Formaldehyde- $\mathrm{NaOH}$ and $\mathrm{NH}_{4} \mathrm{OH}$ chemical method.

(1) $\mathrm{NH}_{4} \mathrm{OH}$ : remaining algae $+0.05 \%(\mathrm{w} / \mathrm{w}) \quad \mathrm{NaCl}$ solution to $100 \mathrm{ml}+50 \mathrm{ml} 0.1 \mathrm{M} \mathrm{NH}_{4} \mathrm{OH}$ at $4{ }^{\circ} \mathrm{C}$ for $1 \mathrm{~h}$.

(2) Formaldehyde- $\mathrm{NaOH}$ : remaining algae $+0.05 \%$ (w/w) $\quad \mathrm{NaCl}$ solution to $100 \mathrm{ml}+50 \mathrm{ml} \quad 36.5 \%$ Formaldehyde- $\mathrm{NaOH}$ at $4{ }^{\circ} \mathrm{C}$ for $1 \mathrm{~h}$.

The treated suspension was centrifuged $(15000 \mathrm{~g})$ for 20 min with the suspension being collected (Fig. 1).

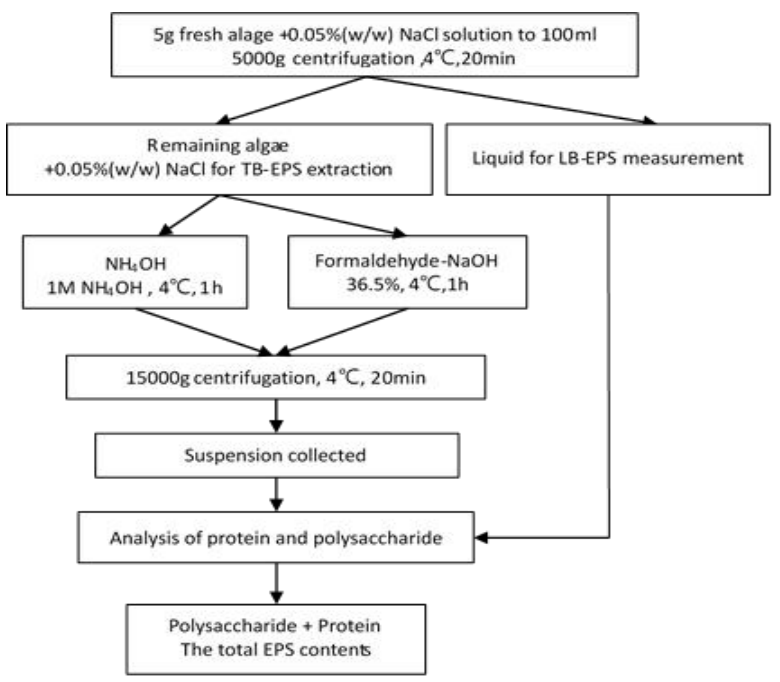

Fig 1. Procedures for the two EPS extraction methods for C.glomerata. 


\section{Analysis Method}

All chemicals used in this work were of analytical grade. Polysaccharide content was determined by the phenol-sulfuric acid using glucose as a standard [14]. Protein content was determined according to Bradford (1976) with bovine serum albumin BSA, Sigma A2153 100mg/ml [15]. The total EPS content was measured as the sum of these two substances.

\section{RESULTS AND DISCUSSION}

\section{A. Microscopy and Comparison of Polysaccharide with} Protein in EPS

Microscopic examination by India ink reverse staining showed appearance of extracellular matrix on the surface of algae cell. The EPS had a gel-like structure that could fractionated into loosely bound EPS (LB-EPS) and tightly bound EPS (TB-EPS) (Fig. 2). Two chemical extraction methods (formaldehyde- $\mathrm{NaOH}$ and $\mathrm{NH}_{4} \mathrm{OH}$ ) were applied to extract the EPS. The EPS and composition resulting are showed in Table I, Fig. 3(Formaldehyde-NaOH method) and Table I, Fig. 4( $\mathrm{NH}_{4} \mathrm{OH}$ method). The formaldehyde- $\mathrm{NaOH}$ method exhibited the higher efficiency, with the polysaccharide and protein contents of $2.3 \mathrm{mg} \mathrm{g}^{-1}$ and $5.5 \mathrm{mg}$ $\mathrm{g}^{-1}$ in the TB-EPS, respectively. Comparing TB-EPS and LB-EPS, the results also show that polysaccharides rather than proteins became the prodominant compositions in TB-EPS.

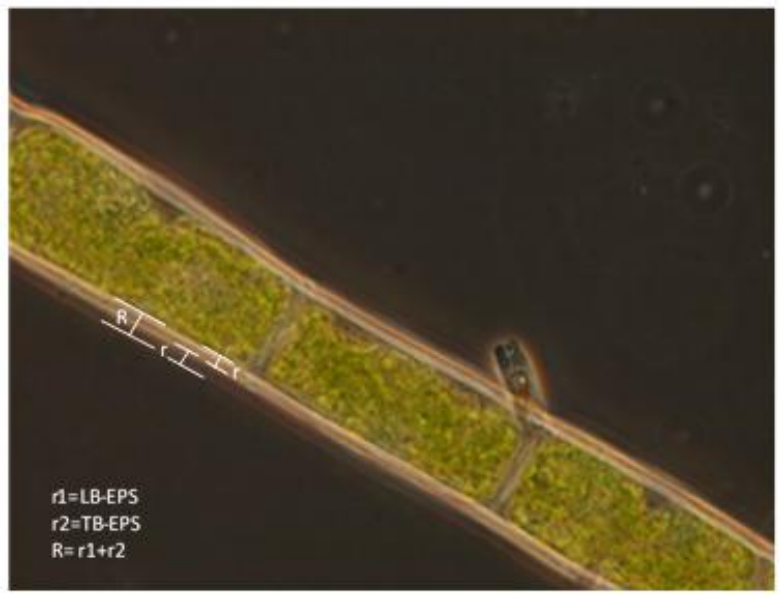

Fig. 2. Mucilage layer stucture of C.glomerata.

\begin{tabular}{|c|c|c|c|c|c|}
\hline \multirow{2}{*}{$\begin{array}{c}\text { Extracted } \\
\text { method } \\
\text { Formaldehyde- } \mathrm{NaOH}\end{array}$} & \multirow[t]{2}{*}{$\begin{array}{c}\text { EPS } \\
\text { extractions }\end{array}$} & \multicolumn{4}{|c|}{ Organic matter contents ( $\mathrm{mg} \mathrm{g}^{-1}$ fresh algae) } \\
\hline & & protein & polysaccharide & $\begin{array}{l}\text { EPS(protein+ } \\
\text { polysaccharide }\end{array}$ & $\begin{array}{c}\text { Potein } \\
\text { /polysaccharide }\end{array}$ \\
\hline & LB-EPS & 2.30 & 0.65 & 2.95 & 3.54 \\
\hline & & 1.86 & 0.59 & 2.45 & 3.15 \\
\hline & & 2.47 & 0.77 & 3.24 & 3.21 \\
\hline & & 1.81 & 0.52 & 2.33 & 3.48 \\
\hline & & 2.03 & 0.69 & 2.72 & 2.94 \\
\hline & & 2.39 & 0.72 & 3.11 & 3.32 \\
\hline & TB-EPS & 2.06 & 6.53 & 8.60 & 0.316 \\
\hline & & 2.35 & 5.47 & 7.82 & 0.324 \\
\hline & & 2.23 & 5.71 & 7.94 & 0.299 \\
\hline & & 2.47 & 4.80 & 7.27 & 0.375 \\
\hline & & 2.65 & 5.68 & 8.33 & 0.346 \\
\hline & & 1.94 & 4.91 & 6.85 & 0.303 \\
\hline
\end{tabular}

\begin{tabular}{|c|c|c|c|c|c|}
\hline \multirow{2}{*}{$\begin{array}{c}\text { Extracted } \\
\text { method }\end{array}$} & \multirow[t]{2}{*}{$\begin{array}{c}\text { EPS } \\
\text { extractions }\end{array}$} & \multicolumn{4}{|c|}{ Organic matter contents (mg g-1 fresh algae) } \\
\hline & & protein & polysaccharide & $\begin{array}{l}\text { EPS(protein+ } \\
\text { polysaccharide }\end{array}$ & $\begin{array}{l}\text { Potein } \\
\text { /polysaccharide }\end{array}$ \\
\hline & LB-EPS & 2.25 & 0.63 & 2.88 & 3.59 \\
\hline & & 2.14 & 0.61 & 2.75 & 3.54 \\
\hline & & 2.38 & 0.82 & 3.19 & 2.91 \\
\hline & & 1.82 & 0.53 & 2.35 & 3.42 \\
\hline & & 1.92 & 0.63 & 2.55 & 3.05 \\
\hline & & 2.35 & 0.74 & 3.09 & 3.16 \\
\hline & TB-EPS & 1.53 & 4.10 & 5.64 & 0.374 \\
\hline & & 1.38 & 3.67 & 5.05 & 0.292 \\
\hline & & 1.48 & 3.73 & 5.21 & 0.303 \\
\hline & & 1.16 & 3.40 & 4.56 & 0.269 \\
\hline & & 1.16 & 4.06 & 5.22 & 0.232 \\
\hline & & 1.15 & 3.29 & 4.44 & 0.275 \\
\hline
\end{tabular}




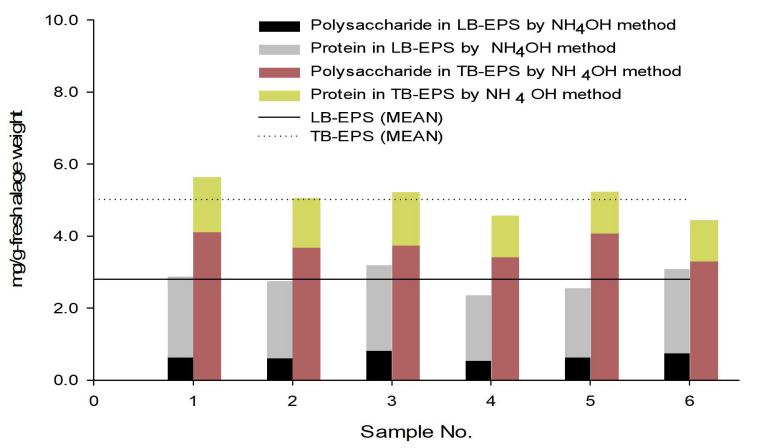

Fig. 3. Comparison protein and polysaccharide in EPS from $\mathrm{NH}_{4} \mathrm{OH}$ extraction method.

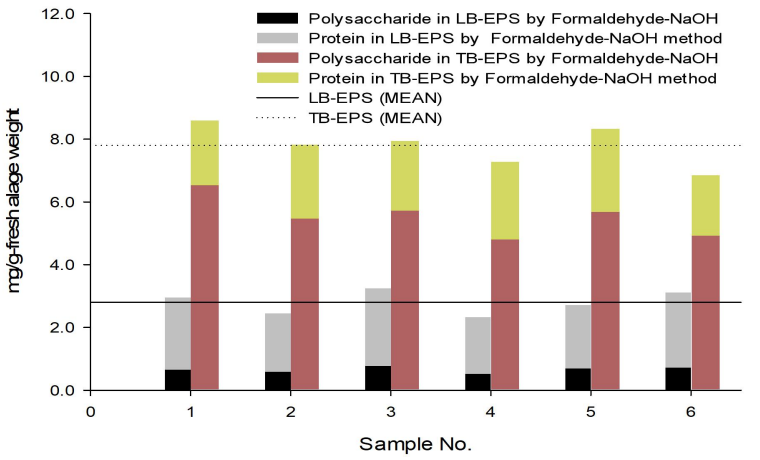

Fig. 4. Comparison protein and polysaccharide in EPS from formaldehyde- $\mathrm{NaOH}$ extraction method.

\section{B. Comparison of Contents and Composition at Different Extraction Method}

The results are shown in Table III and Fig. 5. The data reflect the average results from 6 repeated measurements, which showed that the average EPS extraction yield of formaldehyde- $\mathrm{NaOH}$ is greater than $\mathrm{NH}_{4} \mathrm{OH}$, and the variation of $\mathrm{P} / \mathrm{S}$ ratios.

This study further compared the primary contents of EPS with different extraction methods. The results showed that using different extraction methods can lead to different eatraction yields of EPS, the ratios of protein to polysaccharide in EPS also significant different [16].

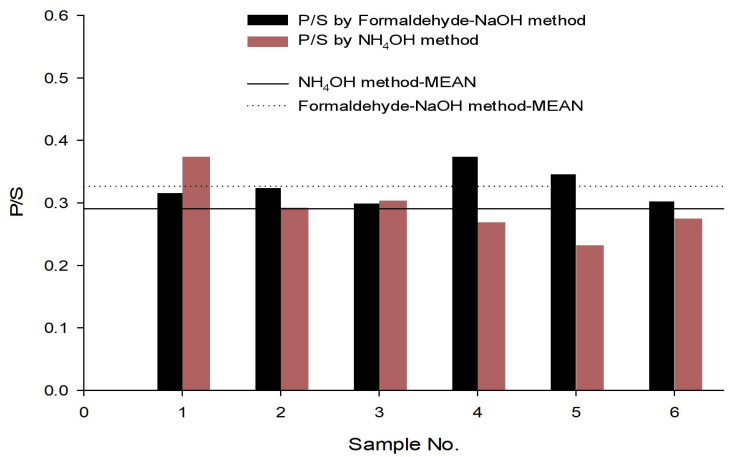

Fig. 5. Comparison protein to polysaccharide ratio in TB-EPS from Formaldehyde- $\mathrm{NaOH}$ and $\mathrm{NH}_{4} \mathrm{OH}$ extraction methods.

TABLE III: COMPARISON OF CONTENTS AND EXTRACTION YIELDS OF EPS BY DIFFERENT EXTRACTION METHODS

\begin{tabular}{cccccc}
\hline \multirow{2}{*}{$\begin{array}{c}\text { EPS } \\
\text { extractions }\end{array}$} & Extracted method & & \multicolumn{3}{c}{ Organic matter contents (mg g-1 fresh algae) } \\
\hline \multirow{3}{*}{ LB-EPS } & protein & polysaccharide & $\begin{array}{c}\text { EPS(protein+ } \\
\text { polysaccharide }\end{array}$ & $\begin{array}{c}\text { Potein } \\
\text { polysaccharide }\end{array}$ \\
\cline { 2 - 6 } & Formaldehyde-NaOH & $2.14 \pm 0.23$ & $0.66 \pm 0.09$ & $2.80 \pm 0.36$ & $3.27 \pm 0.22$ \\
& $\mathrm{NH} 4 \mathrm{OH}$ & $2.14 \pm 0.28$ & $0.66 \pm 0.10$ & $2.80 \pm 0.32$ & $3.28 \pm 0.28$ \\
\cline { 2 - 6 } TB-EPS & Formaldehyde-NaOH & $2.28 \pm 0.26$ & $5.52 \pm 0.63$ & $7.80 \pm 0.65$ & $0.327 \pm 0.028$ \\
& $\mathrm{NH} 4 \mathrm{OH}$ & $1.31 \pm 0.17$ & $3.71 \pm 0.33$ & $5.02 \pm 0.45$ & $0.291 \pm 0.047$ \\
\hline
\end{tabular}

\section{SUMMARY}

In this study of macroalgae EPS, the extraction and analysis of EPS is a most challeging work. To compare the extration yields of EPS from C.glomerata mucilage layer (LB-EPS and TB-EPS) and the changes in its primary contents of polysaccharides and proteins with two different chemical extraction methods (formaldehyde- $\mathrm{NaOH}$ and $\mathrm{NH}_{4} \mathrm{OH}$ ), the study results show that: (1) EPS (Both contents of polysaccharide and protein) could be efficiently extracted by formaldehyde- $\mathrm{NaOH}$ method. (2) The ratios of protein to polysaccharide in LB-EPS are not obvious different.

C.glomerata is a widely distributed dominant macro-green algae. In its natural habitat, C.glomerat has great potential in EPS extraction. These preliminary study results help us understand the extraction methods of EPS applicable to large algae, and the influence on its primary contents.

\section{REFERENCES}

[1] Z. Chi, C. D. Su, and W. D. Lu, "A new exopolysaccharide produced by marine Cyanothece sp. 113.," Bioresource Technol., vol. 98, pp. 1329-1332, 2007.
[2] B. S. McSwain, R. L. Irvine, M. Hausner, and P. A. Wilderer, "Composition and distribution of extracellular polymeric substances in aerobic flocs and granular sludge," Applied and Environmental Microbiology, vol. 71, no. 2, pp. 1051-1057, 2005.

[3] J. Wingender, T. R. Neu, and H. C. Flemming, "Microbial extracellular polymeric substances: characterization, structure and function," Springer Science \& Business Media, 2012

[4] H. Xiaomeng, W. Zhiwei, Z. Chaowei, and Z. Wu, "Effect of ultrasonic power density on extracting loosely bound and tightly bound extracellular polymeric substances," Desalinat., vol. 329, no. 15, pp. 35-40, 2013.

[5] L. P. Wang, Q. R. Shen, G. H. Yu, W. Ran, and Y. C. Xu, "Fate of biopolymers during rapeseed meal and wheat bran composting as studied by two-dimensional correlation spectroscopy in combination with multiple fluorescence labeling techniques," Bioresour. Technol., vol. 105, pp. 88-94, 2012.

[6] G. P. Sheng, H. Q. Yu, and X. Y. Li, "Extracellular polymeric substances (EPS) of microbial aggregates in biological wastewater treatmentsystems: A review," Biotechnology Advances, vol. 28, pp. 882-894, 2010.

[7] W. K. Dodds and D. A. Gudder, "The ecology of Cladophora," Journal of Phycology, vol. 28, pp. 415-427, 1992.

[8] R. Xiao and Y. Zheng, "Overview of microalgal extracellular polymeric substances (EPS) and their applications," Biotechnology Advances, vol. 34, pp. 1225-1244, 2016.

[9] L. Shen, Z. F. Li, J. J. Wang, A. Liu, Z. H. Li, R. L. Yu, X. L. Wu, Y. D. Liu, J. K. Li, and W. M. Zeng, "Characterization of extracellular polysaccharide/protein contents during the adsorption 
of Cd(II) by Synechocystis sp. PCC6803," Environmental Science and Pollution Research, vol. 25, pp. 20713-20722, 2018.

[10] C. J. Tien, V. Krivtsov, E. Levado, D. C. Sigee, and K. N. White, "Occurrence of cell-associated mucilage and soluble extracellular polisaccharides in Rostherne Mere and their possible significance," Hydrobiologia, vol. 485, no. 1-3, pp. 245-252, 2002.

[11] Y. T. Chiou, M. L. Hsieh, and H. H. Yeh, "Effect of algal extracellular polymer substances on UF membrane fouling," Desalination, vol. 250, pp. $648-652,2010$

[12] X. Huacheng, Y. Guanghui, and J. Helong Jiang, "Investigation on extracellular polymeric substances from mucilaginous cyanobacterial blooms in eutrophic freshwater lakes," Chemosphere, vol. 93, pp. 75-81, 2013.

[13] N. Lixiao, L. Danye, R. Shiyi, S. Lili, Z. Wei, W. Peifang, W. Chao, L. Shiyin, and A. Kumud, "Characterization of extracellular polymeric substance (EPS) fractions produced by Microcystis aeruginosa under the stress of linoleic acid sustained-release microspheres," Environmental Science and Pollution Research, vol. 24, pp. 21091-21102, 2017.

[14] M. Dubois, K. A. Gilles, J. K. Hamilton, P. A. Rebers, and F. Smith, "Colorimetric method for determination of sugars and related substances," Anal. Chem., vol. 28, no. 3, pp. 350-356, 1956.

[15] M. M. Bradford, "A rapid and sensitive method for the quantitation of microgram quantities of protein utilizing the principle of protein-dye binding," Anal. Biochem., vol. 72, pp. 248-254, 1976.

[16] B. Mahendran, F. Jared, and N. L. Steven, "Protein and polysaccharide content of tightly and loosely bound extracellular polymeric substances and the development of a granular activated sludge floc," Water Research, vol. 82, pp. 104-117, 2015.

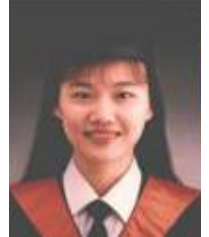

Hwey-Lin Sheu was original born in Taiwan, Nantow. Her date of birth is $1969 / 01 / 03$. She is an associate professor at the Department of Environment Engineering, Kun Shan University in Taiwan, Tainan. She received her Ph.D. degree at National Cheng Kung University in Taiwan. Her main research areas focus on the protection of environment.

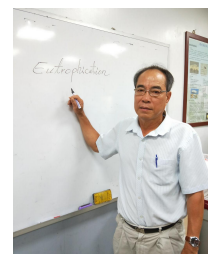

Shui-Ping Chang was born in Taiwan, in 1954. In 1973-1977, he obtained his B.S. in Botany, National Chung Hsing University, Taichung, Taiwan. In 1982-1985, he got his M.S. in environmental science, SUNY at Syrcause, New york, U.S.A. In 1992-1997, he was a Ph.D. of Environmental Engineering, National Cheng Kung University.

In 1985-1992, he works as a senior engineer and section chief at EPA in Taiwan. From 1997 to present, he is an associate professor at the Department of Environment Engineering, Kun Shan University in Taiwan. His Reseach intersits are algae, bioremediation, water treatment.

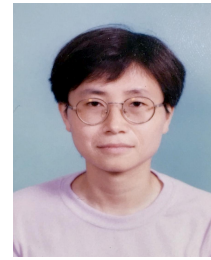

Yi-Chao Lee was born in Taiwan, Chiayi. Her date of birth is $1966 / 11 / 14$. She is an assistant professor at the Department of Environment Engineering, Kun Shan University in Taiwan, Tainan. She obtained a master's degree in civil engineering from National Chiao Tung University in Taiwan. Her main research areas focus on the environmental engineering. 